\title{
TINJAUAN TEOLOGIS TERHADAP PENGAJARAN MEMPELAI DALAM TERANG TABERNAKEL
}

\author{
Kasieli Zebua \\ kasielizebua@gmail.com
}

\begin{abstract}
Abstrak
Pengajaran Mempelai dalam Terang Tabernakel merupakan kebanggan yang diwariskan oleh F. G. van Gessel yang diyakini sebagai kebenaran yang Alkitabiah. Pengajaran ini telah memberkati begitu banyak jemaat Tuhan khususnya di lingkungan Gereja Pantekosta Tabernakel. Tentu saja topik ini sangat poluler di lingkungan Gereja Pantekosta Tabernakel, namun demikian mungkin sesuatu yang asing bagi gereja-gereja yang lain. Oleh sebab itu melalui tulisan singkat ini, penulis berusaha memberikan gambaran singkat tentang latar belakang, perkembangan serta konsep dasar dari Pengajaran ini sehingga setiap kalangan dapat memahami apa yang dimaksud dengan Pengajaran Mempelai dalam Terang Tabernakel. Tulisan ini tidak bermaksud menjelaskan detail dari Pengajaran ini dan bagaimana metode penafsiran digunakan, tetapi hanya sebatas mengungkapkan bagaimana korelasi Pengajaran Mempelai dengan Pengajaran Tabernakel. Pengajaran Mempelai berbicara tentang relasi yang akan dicapai, sedangkan Pengajaran Tabernakel berbicara tentang Karya Kristus yang memungkinkan tercapainya relasi tersebut.
\end{abstract}

Kata Kunci: Pengajaran, Mempelai, Relasi, Tabernakel, Karya Kristus

\begin{abstract}
The teaching of Bride Tidings in the light of the Tabernacle is a pride handed down by Rev. F. G. van Gessel that we believe to be biblical truth. This teaching has blessed so many people of God, especially in the Gereja Pantekosta Tabernakel (Tabernacle Pentecostal Church). Of course this topic is very familiar in Gereja Pantekosta Tabernakel (Tabernacle Pentecostal Church), though may be it is still something unfamiliar to the other conggragations.. Therefore through this short article, the author tries to give a brief description of the background, the development and basic concept of this teaching so the reader can understand what is meant by the Bride Tidings in the light of the Tabernacle doctrine. This article does not intend to explain the details of the doctrine and the hermeneutics method is used, but just to describe how the Bride Tidings with Tabernacle doctrine correlated. The Bride Tidings is all about the relationship that will be achieved, while the Tabernacle doctrine is talks about the Work of Christ that makes the relationship possible.
\end{abstract}

Keywords: Teaching, the Bride, Relation, Tabernacle, Work of Christ 


\section{PENDAHULUAN}

Gereja yang kokoh ialah gereja yang memiliki pengajaran firman yang benar. Dengan pengajaran yang kuat Gereja Tuhan akan terbangun, terbentuk dan eksis hingga pada kesempurnaan. Apa yang digagas dan dihasilkan oleh F. G. van Gessel ${ }^{1}$ mencerminkan hal tersebut. Melalui pengalaman pribadi dengan Tuhan dalam firmanNya telah memberikan keyakinan yang teguh dalam hatinya akan kebenaran "Pengajaran Tabernakel."2

Pengajaran Tabernakel merupakan hasil penyelidikan dan perenungan Alkitab yang intensif dan mendalam yang dilakukan oleh F. G. van Gessel sejak tahun 1935 di Cepu. Tema ini lahir dari pemahaman firman Allah yang mendalam dan komprehensif, serta keyakinan dan kerinduan agar Gereja Tuhan dipersiapkan untuk menjadi Mempelai Wanita Kristus yang sempurna. Pengajaran Tabernakel membawa serta mengarahkan kehidupan umat Tuhan untuk menjadi Mempelai Wanita Kristus.

F. G. van Gessel sendiri telah menjadi pelopor dalam menyampaikan firman Tuhan melalui tema besar ini. Pada Tahun 1952, F. G. van Gessel dan H. C. Senduk mendirikan Gereja Bethel Injil Sepenuh (GBIS) dengan pengajarannya tentang Tabernakel. ${ }^{3}$ Pada tahun 1954, ia berangkat ke Papua dan mendirikan Gereja Bethel Gereja Pantekosta (GBGP) dan semakin mendalami serta mengajarkan mengenai Tabernakel. ${ }^{4}$

C. Totaijs ${ }^{5}$ yang disebut sebagai ahli waris pengajaran ini terus menyebarkannya di Belanda. Dari Belanda berita ini telah mencapai beberapa negara di Eropa, Afrika, Amerika dan Asia. ${ }^{6}$ Sedangkan perkembangan yang signifikan di Indonesia terutama dilakukan oleh In Yuwono, salah seorang murid dari F. G. van Gessel. ${ }^{7}$ Perkembangan tersebut terjadi dalam organisasi Gereja Pantekosta Tabernakel (GPT) ${ }^{8}$ yang didirikan oleh In Yuwono pada tahun 1970. Sejak waktu itu pengajaran ini berkembang mulai dari Surabaya hingga ke propinsi-propinsi lainnya di Indonesia, bahkan ke luar negeri.

"Pengaran Mempelai dalam Terang Tabernakel" merupakan main topic dari Gereja Pantekosta Tabernakel (GPT), yang diyakini sebagai warisan pengajaran yang harus dipegang dan diberitakan. Hal ini terbukti di dalam AD/ART GPT pada Bab 2 pasal 5 mengenai Identitas Gereja menyatakan bahwa Gereja Pantekosta Tabernakel adalah organisasi kerohanian yang membawa, membina dan mendewasakan umat menuju kehidupan sempurna, dengan pengajaran Alkitab seutuhnya yang disebut Pengajaran Tabernakel dan Pengajaran Mempelai. ${ }^{9}$ Kemudian pasal 6 ayat 1 mengenai Asas, menyatakan bahwa seluruh keberadaan Gereja Pantekosta Tabernakel sebagai organisasi, berasaskan kebenaran Alkitab seutuhnya yang disebut dengan Pengajaran Mempelai dalam Terang Tabernakel. ${ }^{10}$ Gereja Pantekosta Tabernakel bertujuan untuk

${ }^{1}$ Nama lengkap ialah Pdt. Fredrick George van Gessel disingkat F. G. van Gessel.

${ }^{2}$ Lidya Julianti \& Tim, Biografi F. G. van Gessel, (Surabaya: SAPTA KMI, tt), 5.

${ }^{3}$ Sejarah GPT, (https://id.wikipedia.org/wiki/Gereja_Pantekosta_Tabernakel, 13 Juli 2010).

${ }^{4}$ Pengajaran Kabar Mempelai (http://kabar-mempelai.blogspot.com/, 19 Juli 2019)

${ }^{5}$ Pdt. C. Titaijs adalah menantu laki-laki dari Pdt. F. G van Gessel

${ }^{6}$ Sejarah Gereja (http://gptkk.org/m/sejarah.php, 19 Juli 2019)

${ }^{7}$ Pdt. In Yuwono (1927-1989) adalah salah seorang murid dari F. G. van Gessel yang melanjutkan Pengajaran Mempelai dalam Terang Tabernakel.

${ }^{8}$ Gereja Pantekosta Tebernakel (GPT) termasuk salah satu anggota Persekutuan Gereja Pentakosta Indonesia (PGPI).

${ }^{9}$ Anggaran Dasar Anggaran Rumah Tangga Gereja Pantekosta Tabernakel (SK. Dirjen Bimas Kristen Departemen Agama No. 58 Tahun 1987 Anggota PGPI No. 63), 8

${ }^{10}$ Anggaran Dasar Anggaran Rumah Tangga Gereja Pantekosta Tabernakel, 8. 
menyebarkan Firman Pengajaran Mempelai dalam Terang Tabernakel kepada seluruh dunia. $^{11}$

Semangat dalam mengestafetkan dan memberitakan Pengajaran Mempelai dalam Terang Tabernakel dilakukan dengan berbagai cara, baik melalui penginjilan pribadi hingga pembukaan gereja lokal baru di berbagai daerah di Indonesia, mendirikan sekolah Alkitab, mengadakan KKR atau Pendalaman dan Penyegaran Iman (PPI), dll. ${ }^{12}$

Militansi terhadap Pengajaran Mempelai dalam Terang Tabernakel tidak diragukan lagi khususnya bagi hamba-hamba Tuhan yang telah belajar dan menerima pengajaran ini langsung dari F. G. van Gessel maupun dari murid-muridnya terutama dari In Yuwono sebagai founding father GPT dan Lembaga Pendidikan Elkitab (LEMPIN-EL) di Jalan Johor 47 Surabaya.

Untuk efektifitas sehingga pengajaran ini dapat tersebar dengan cepat, In Yuwono mendirikan Lembaga Pendidikan Elkitab (LEMPIN-EL) sebagai tempat mempersiapkan hamba-hamba Tuhan menjadi penerus-penerus yang menyebarkan pengajaran ini. Lembaga Pendidikan Elkitab (LEMPIN-EL) yang pertama kali didirikan tahun 1968 oleh In Yuwono di Jl. Johor 47 Surabaya dan di kemudian hari juga di beberapa tempat di Indonesia beberapa hamba-hamba Tuhan GPT, alumni dari LEMPIN-EL mendirikan sekolah Alkitab yang serupa hanya untuk mengajarkan dan mengestafetkan pengajaran ini, bahkan sampai pendidikan tinggi (Sekolah Tinggi Teologi) ${ }^{13}$ dan yang terakhir ialah SALEM (Sekolah Alkitab LEMPIN-EL) yang secara resmi dibuka pada tanggal 11 Mei 2017 dengan tujuan utama ialah mengestafetkan Pengajaran Mempelai dalam Terang Tabernakel. ${ }^{14}$

Keyakinan pada kebenaran Pengajaran Mempelai dalam Terang Tabernakel sebagai Firman Pengajaran yang Alkitabiah, telah membangkitkan kerinduan yang besar untuk memberitakannya bukan hanya dalam organisasi GPT, tetapi juga kepada setiap orang bahkan sampai kepada seluruh dunia sesuai dengan Amanat Agung Tuhan Yesus. Sejak tahun 1969, In Yuwono bekerja sama dengan C. Totaijs yang ada di Belanda dibantu oleh hamba-hamba Tuhan yang lain mendirikan sebuah lembaga yang mewadahi tercapainya tujuan tersebut, yaitu Pendalaman dan Penyegaran Iman Kabar Mempelai Internasional (PPI KMI), dalam bahasa Inggris, Bride Tidings International Conference (BTIC). ${ }^{15}$ PPI KMI (BTIC) telah menjangkau hampir seluruh propinsi di Indonesia dan juga beberapa negara di luar negeri.

Namun demikian dalam perkembangan hingga hari ini, Pengajaran Mempelai dalam Terang Tabernakel ini mengalami multi tafsir yang berbeda-beda. Hal ini terjadi terutama karena sangat terbatasnya literatur tentang Pengajaran Mempelai dalam Terang Tabernakel, baik yang ditulis oleh F. G. van Gessel maupun yang ditulisan oleh muridmuridnya. Maka dalam tulisan singkat ini, penulis berusaha memberikan penjelasan

${ }^{11}$ Gereja Panteksota Tabernakel, (https://id.wikipedia.org/wiki/Gereja_Pantekosta Tabernakel, 17 Juli 2019)

${ }^{12}$ Pendalaman dan Penyegaran Iman (PPI) biasanya dilakukan selama 3 hari dimana sesi-sesi di dalamnya terdiri atas Pendalaman Alkitab dan juga Kebaktian Kebangunan Rohani (KKR).

${ }^{13}$ Sekolah Tinggi Teologi Tabernakel Indonesia yang didirikan pada tanggal 24 Agustus 2007 bertempat di Jl. Johor 47 Surabaya di bawah naungan Yayasan Pembinaan Kerokhanian Tabernakel milik dari gereja lokal, yaitu GPT Kristus Ajaib J1. Johor 47 Surabaya dan GPT Kristus Gembala J1. Lemah Putro I/18 Surabaya.

${ }^{14}$ Pembukaan SALEM dilaksanakan dalam acara KKR GPT yang diadakan pada tanggal 9-11 Mei 2017 di Golden City Mall (Goci) Surabaya. SALEM merupakan Sekolah Alkitab yang didirikan langsung oleh Sinode GPT dan secara resmi dibuka oleh Ketua Umum GPT periode 2015-2020, yaitu Pdt. Paulus Budiono.

${ }^{15}$ Sejarah Gereja, (http://gptkk.org/m/sejarah.php, 19 Juli 2019) 
mengenai beberapa terminologi penting serta konsep besar dari Pengajaran Mempelai dalam Terang Tabernakel.

\section{TERMINOLOGI DAN KONSEP}

\section{Definisi Istilah}

Kata "Terang" dalam tema Pengajaran Mempelai dalam Terang Tabernakel dapat memiliki pengertian: memperjelas, membuat menjadi jelas. Artinya bahwa pengajaran Tabernakel memperjelas atau membuat menjadi jelas apa yang dimaksud dengan Pengajaran Mempelai. Dapat juga berarti bahwa Pengajaran Tabernakel menjelaskan apa yang dimaksud dengan Pengajaran Mempelai. Dan bisa juga dipahami bahwa dengan Pengajaran Tabernakel, Pengajaran Mempelai menjadi lebih jelas, lebih terang.

Alternatif lain dalam memahami kata "Terang" di sana dapat didefinisikan sebagai sudut pandang, kaca mata, atau dengan bahasa yang lebih keren ialah perspektif. Mungkin pengertian ini sedikit bergeser dari apa yang maksudkan, tetapi dengan pengertian ini akan memberikan pemahaman yang mudah dipahami ketika berbicara mengenai Pengajaran Mempelai. Sehingga dengan pengertian ini, maka dapat diartikan menjadi "Pengajaran Mempelai dalam perspektif Tabernakel".

Pada awalnya F. G. van Gessel lebih dahulu memperkenalkan Pengajaran Tabernakel yaitu sejak tahun 1935, setelah itu baru Pengajaran Pengantin. Pengajaran Pengantin ini sangat erat hubungannya dengan pengajaran Tabernakel, dan tidak boleh terpisahkan, yang dikemudian hari disebut dengan Pengajaran Mempelai. ${ }^{16}$

Istilah dan sebutan "Pengajaran Mempelai dalam Terang Tabernakel" tidak diketahui secara pasti kapan dikumandangkan, namun menurut Paulus Budiono dalam wawancara pada tanggal 11 Juli 2019 menyampaikan bahwa munculnya pertama kali istilah Pengajaran Mempelai dalam Terang Tabernakel tidak tahu kapan persisinya, yang jelas pada waktu LEMPIN-EL Angkatan I tahun 1968, Pengajaran Mempelai belum diajarkan. Yang diajarkan ialah Pengajaran Tabernakel.

Dari pernyataan di atas diketahui bahwa istilah Pengaran Mempelai dalam Terang Tabernakel lahir setelah F. G. van Gessel, tetapi benih-benihnya ia yang memulai. Apabila istilah tersebut lahir dalam perjalanan LEMPIN-EL, maka kemungkinan besar istilah tersebut dikumandangkan pada zaman In Yuwono.

\section{Alkitab Sebagai Dasar Pengajaran Mempelai}

Pengajaran Mempelai bersumber dari Alkitab. Alkitab sebagai kebenaran mutlak, maka tentu saja Pengajaran Mempelai juga harus dilihat dalam perspektif Alkitab. Alkitab adalah dasar dari pengajaran Mempelai, artinya pengajaran mempelai harus dilihat dari perspektif Alkitab.

\section{Mempelai Sebagai Relasi Tertinggi}

Allah membangun relasi dengan manusia dalam berbagai analogi di Alkitab. Salah satunya ialah relasi sebagai mempelai (suami istri). Relasi ini merupakan relasi yang terintim dari segala relasi yang dapat dipahami oleh manusia. Mempelai berbicara tentang gambaran relasi Kristus dengan gereja-Nya yang merupakan tujuan terakhir dari Allah bagi manusia. Manusia kembali dalam relasi yang baru dan intim dengan Dia, yang digambarkan sebagai relasi suami-istri atau Mempelai.

\footnotetext{
${ }^{16}$ Paulus Budiono, dkk. Pengajaran Mempelai (Surabaya: SAPTA KMI, tt) 3.
} 
Dalam Alkitab, relasi Allah dan manusia dinyatakan dalam berbagai analogi supaya manusia menyadari bahwa bahwa ia memiliki relasi dengan Allah sekaligus menyadari bahwa Allah merindukan relasi tersebut. Relasi yang dimaksud antara lain: (a) sebagai Pencipta dan ciptaan (Pkh. 12:1), (b) sebagai Allah dan umat (Kej. 17:7), (c) sebagai Raja dan hamba (Mat. 18:23), (d) sebagai Gembala dan domba (Yeh. 34:15; Yoh. 10), (e) sebagai Juruselamat dan orang percaya (1 Tim. 4:10), (f) sebagai Bapa dan anak (Luk. 15:12), (g) sebagai Guru dan murid (Luk. 8:24), (h) sebagai Sahabat (Yoh. 15:13-15), (i) sebagai kepala dan tubuh (Ef. 5:23; 1:23), dan (j) sebagai Mempelai Pria Dan Mempelai Wanita (Hos. 2:18-19; Why. 19:7-9). ${ }^{17}$ Relasi Kristus sebagai Mempelai Pria dan gereja sebagai mempelai wanita-Nya merupakan relasi tertinggi dan terintim dari analogi tersebut.

Dalam kitab Hosea digambarkan hubungan Allah dan umat Israel yang khusus, yaitu TUHAN mengibaratkan diri-Nya sebagai "Suami" dan umat Israel sebagai "istri”. Tetapi sebagai "istri", umat Israel telah berselingkuh, bahkan bersundal. Mereka telah bersundal kepada yang bukan suaminya, yaitu kepada Baal dan ilah-ilah lain. Masih layakkah umat itu dikasihi? Sebenarnya mereka sudah tidak layak untuk dikasihi lagi. Kendatipun demikian, Allah tetap mengasihi mereka. Allah memberi contoh tentang "to love the unlove". ${ }^{18}$

Dalam Hosea 2:18-19 TUHAN berfirman: Aku akan menjadikan engkau isteri-Ku untuk selama-lamanya dan Aku akan menjadikan engkau isteri-Ku dalam keadilan dan kebenaran, dalam kasih setia dan kasih sayang. Aku akan menjadikan engkau isteri-Ku dalam kesetiaan, sehingga engkau akan mengenal TUHAN.

Ayat ini menyatakan isi hati Allah bagaimana Allah mengambil inisiatif untuk membangun hubungan dengan manusia dalam hubungan yang begitu erat. Kerinduan Allah dapat dipahami dalam seluruh Alkitab, dari kejatuhan manusia dalam dosa hingga kesatuan yang kekal yang dinyatakan dalam pernikahan Anak Domba. Allah memiliki rencana dan kerinduan yang besar terhadap manusia ciptaan-Nya, sesuai dengan rencana awal ketika Ia menciptakan manusia. Ia menghendaki manusia yang segambar dan serupa dengan Dia memiliki relasi yang harmonis dan menjadi mitra kerja-Nya di dunia. ${ }^{19}$

Dari ayat-ayat di atas, tiga kali Allah menyampaikan, Aku akan menjadikan engkau istriku. Dalam bahasa Ibrani, kata "istri" di sini אָרש '(aras), artinya betroth, engage, yaitu menjadikan tunangan. Allah menyampaikan hal tersebut sampai tiga kali menunjukkan keseriusan dan komitmen Allah dalam membangun relasi itu. Allah tidak sembarangan dan tidak asal-asalan ketika Ia mau mengikatkan diri-Nya dengan manusia. Allah sungguh-sungguh serius.

Ketika Allah menyatakan bahwa Ia mau menjadikan Israel sebagai istri-Nya, dengan kata lain Ia mau menjadi suami bagi umat itu, sekaligus Ia menyatakan komitmen-Nya. Di dalam relasi sebagai suami istri ini (marital relationship), terlihat betapa Allah memiliki komitmen dan ketulusan serta cinta yang dalam kepada umatNya. Dengan komitmen dan inisiatif Pribadi, Allah menyatakan bahwa hubungan yang Ia

${ }^{17}$ Jarot Wijanarko, Mempelai Ilahi, (Jakarta: KIB, 2017), 16.

${ }^{18}$ A. de Kuiper, Tafsiran Alkitab - Kitab Hosea, (Jakarta: BPK Gunung Mulia, 2003), 55.

${ }^{19} \mathrm{Di}$ Israel, pria yang telah bertunangan juga disebut sebagai "suami" dan gadisnya sebagai "istri" (Ulangan 22:23, 24; Matius 1:18-20). Laki-laki akan bertunangan dengan perempuan, atau mengadakan perjanjian untuk menikah, dengan cara membayar mas kawin, atau uang pembelian, kepada ayah si perempuan atau walinya (Keluaran 22:16, 17). Perempuan itu kemudian menjadi miliknya (Keluaran 20:17). Kata Ibrani בֵַ (ba'al), harfiah: pemilik/ tuan/ suami, digunakan untuknya, dan wanita itu disebut sebagai בַּעוּדָה (be'ulah), artinya "dimiliki sebagai seorang istri" (Kejadian 20:3; Ulangan 22:22; Yesaya 62:4) Charles F. Pfeiffer \& Everett F. Harrison (ed), Tafsiran Alkitab Wycliffe Volume 2, (Malang: Gandum Mas, 2005), 43. 
bangun dengan Israel, umat-Nya dengan karakterikstik sebagai berikut: (1) untuk selama-lamanya, (2) dalam keadilan, (3) dalam kebenaran, (4) dalam kasih setia, (5) dalam kasih sayang, dan (6) dalam kesetiaan. Semuanya ini bertujuan: sehingga engkau mengenal TUHAN.

Dengan demikian, karakteristik dalam relasi yang dibangun oleh Allah merupakan karakteristik dari Allah sendiri. Dari pihak Allah, Ia tidak mungkin mengingkari relasi tersebut.

\section{Mempelai sebagai Relasi Eksklusif}

Frasa "Aku akan menjadikan engkau isteri-Ku" menyatakan bahwa Tuhanlah yang mengambil inisiatif dalam memulai hubungan itu. Di dalam frasa ini mengandung tujuan tertinggi dan kerinduan terdalam dari Allah. Ia merindukan hubungan yang intim (Intimacy Relationship) dan eksklusif. Allah sebagai pencipta nikah pada mulanya menunjukkan bahwa relasi sebagai suami istri merupakan relasi tertinggi daripada relasi yang lain.

Hosea 2:19, Aku akan menjadikan engkau isteri-Ku dalam kesetiaan, sehingga engkau akan mengenal TUHAN." Kata "mengenal" dari kata Ibrani ?ָּ (yada) artinya to know. ${ }^{20}$ Strong's H3045, kata ידָ (yada) didefinisikan: memahami, mengetahui, mencari tahu, mengetahui dari pengalaman, mengenal seseorang, mengenali, pernah mengalami, merawat seseorang (mengenal seseorang secara seksual seperti dalam pernikahan).

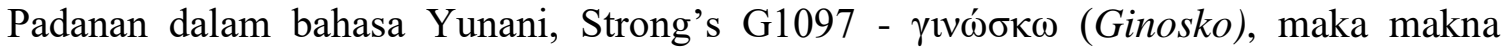
esensi dari kata yada maupun ginosko adalah "Pengetahuan Yang Didapat Melalui Pengalaman" (experiental knowladge). ${ }^{21}$

Artinya ידע (yada') dalam ayat ini berarti suatu pengetahuan yang didapatkan melalui pengalaman dalam Intimacy Relationship dengan Allah, yaitu ketika manusia mengalami: keadilan dan kebenaran, kasih setia dan kasih sayang, dan kesetiaan TUHAN.

\section{Mempelai sebagai Karya Allah}

Aku akan menjadikan engkau isteri-Ku. Yang menjadikan umat menjadi istri-Nya adalah TUHAN sendiri. Dalam konteks ayat ini, Allah menjanjikan pemulihan kepada Israel setelah mereka memberontak kepada-Nya. Sungguh menarik bahwa TUHAN tidak berkata kepada mereka, Aku akan mengampunimu, atau Aku akan memulihkan keadaanmu, atau Aku akan memberkatimu, atau Aku akan menerimamu kembali, tetapi Ia berkata, Aku akan menjadikan engkau isteri-Ku.

Allah langsung membawa mereka kepada relasi yang tertinggi dalam keintiman dengan Dia. Allah tidak hanya membebaskan mereka dari hukuman dan mencurahkan pengampunan-Nya, tetapi semua hal itu dikerjakan oleh Allah dengan tujuan yang tertinggi yaitu manusia mengalami intimacy relationship dengan Dia melalui yada yaitu pengenalan yang sempurna melalui pengalaman relasi yang intim dengan TUHAN.

TUHAN berkata, Aku akan menjadikan engkau isteri-Ku. Kata "akan" atau dalam bahasa Inggris "will" adalah kata keterangan yang berfungsi menerangkan kata kerja, kata sifat atau kata keterangan lainnya, yaitu menyatakan sesuatu yang hendak terjadi. Artinya bahwa apa yang dikerjakan oleh TUHAN yaitu "menjadikan Israel menjadi Istri-Nya" sesuatu yang hendak terjadi.

Bagaimana Allah mengerjakan hal itu? Secara singkat dapat dilihat dalam pembukaan surat Ibrani, ketika penulis surat tersebut mengungkapkan bagaimana Allah

\footnotetext{
${ }^{20}$ Bible Works 8 - version 8.0.013z.1.

${ }^{21}$ Strong's Concordance, https://biblehub.com/hebrew/3045.htm, 07 Juli 2019.
} 
berkomunikasi dengan manusia, sejak pada zaman dahulu hingga pada zaman akhir. Ibrani 1:1-4,

Setelah pada zaman dahulu Allah berulang kali dan dalam pelbagai cara berbicara kepada nenek moyang kita dengan perantaraan nabi-nabi, maka pada zaman akhir ini Ia telah berbicara kepada kita dengan perantaraan Anak-Nya, yang telah Ia tetapkan sebagai yang berhak menerima segala yang ada. Oleh Dia Allah telah menjadikan alam semesta. Ia adalah cahaya kemuliaan Allah dan gambar wujud Allah dan menopang segala yang ada dengan firman-Nya yang penuh kekuasaan. Dan setelah Ia selesai mengadakan penyucian dosa, Ia duduk di sebelah kanan Yang Mahabesar, di tempat yang tinggi, jauh lebih tinggi dari pada malaikat-malaikat, sama seperti nama yang dikaruniakan kepada-Nya jauh lebih indah dari pada nama mereka.

Relasi tersebut dikerjakan dalam bentuk komunikasi untuk mengkomunikasikan diri-Nya dan rencana serta kerinduan-Nya bagi manusia. Ayat-ayat ini memperlihatkan bahwa Allah berbicara untuk mengkomunikasikan diri-Nya secara progresif, yaitu sebagai berikut: (a) Allah berbicara, (b) Allah berbicara berulang-kali, (c) Allah berbicara dalam pelbagai cara, (d) Allah berbicara kepada nenek moyang kita, (e) Allah berbicara dengan perantaraan nabi-nabi, dan (f) Allah berbicara dengan perantaraan Anak-Nya.

Dalam pemahaman secara komprehensif, sejak penciptaan manusia, kemudian manusia jatuh dalam dosa, Allah terus-menerus berusaha membangun komunikasi dengan manusia hingga hari ini. Dengan demikian, Relasi yang dibangun oleh Allah sejak zaman dahulu semuanya digenapi melalui Komunikasi dengan perantaraan AnakNya, Yesus Kristus. Melalui Kristus, penyataan Diri Allah, rencana dan kerinduan hatiNya dinyatakan dengan sempurna. Segala upaya Allah dalam membangun relasi dengan manusia diwujud-nyatakan hanya melalui Anak-Nya, Yesus Kristus. Dengan demikian, tidak akan ada relasi yang tercipta diluar dari relasi yang dibangun melalui melalui Kristus. Kristus satu-satunya jalan terciptanya relasi itu.

\section{Mempelai dalam Ikatan Perjanjian}

Di dalam Perjanjian Lama, kata "perjanjian" Ibrani ִִּרִִּ (beriyth, artinya covenant. Sedangkan di dalam Perjanjian Baru menggunakan istilah $\delta i \alpha \theta \eta \dot{\kappa \eta}$ (diatheke). Kedua istilah ini secara umum mempunyai pengertian adanya perjanjian yang dibuat antara dua pihak dengan berbagai persyaratan, tata cata dan konsekuensi yang ada di dalamnya. Sementara secara khusus - jika kemudian dikaitkan dengan pengertian perjanjian Allah, hal ini berarti sebuah perjanjian yang ditetapkan Allah sebagai Pencipta dan manusia sebagai ciptaan. Tentu saja kedua pihak ini tidak dapat dilihat di dalam kedudukan yang sejajar.

Yeremia 31:31-32, Sesungguhnya, akan datang waktunya, demikianlah firman TUHAN, Aku akan mengadakan perjanjian baru dengan kaum Israel dan kaum Yehuda, bukan seperti perjanjian yang telah Kuadakan dengan nenek moyang mereka pada waktu Aku memegang tangan mereka untuk membawa mereka keluar dari tanah Mesir; perjanjian-Ku itu telah mereka ingkari, meskipun Aku menjadi tuan yang berkuasa atas mereka, demikianlah firman TUHAN.

Perjanjian ini dilakukan oleh Allah sendiri di dalam inisiatif-Nya yang mutlak untuk mengikat Perjanjian dengan manusia. Bahwa Allah menghendaki adanya ketaatan sepenuhnya dari manusia kepada-Nya dan bahwa Allah di dalam kerelaan kehendakNya mengikatkan Diri di dalam janji mencurahkan berkat-Nya jika manusia menuruti di 
dalam ketaatan kepada kehendak-Nya. Dengan demikian, covenant ini merupakan perjanjian tanpa syarat, baik dari pihak Allah sebagai pembuat perjanjian, maupun dari sisi umat sebagai pelaksana perjanjian tersebut.

Dari ayat di atas kita dapat mengidentifikasi siapakah TUHAN yang berjanji kepada Israel ketika Ia memegang tangan mereka dan membawa mereka keluar dari Mesir. TUHAN menjelaskan bahwa status atau posisinya yaitu sebagai tuan yang berkuasa atas mereka. Kata "tuan" dalam ayat tersebut sesuai bahasa Ibrani בּע (ba al) artinya husband, suami. Dengan demikian, perjanjian yang diadakan oleh TUHAN dengan umat-Nya, Israel, adalah perjanjian dalam relasi seperti hubungan suami istri. Allah menempatkan diri-Nya sebagai Suami dan Israel sebagai istri-Nya.

Apakah isi perjanjian itu? Perjanjian itu adalah 10 hukum yang diberikan kepada Musa di atas gunung Sinai yang ditulis di dalam kedua loh batu. Perjanjian ini kemudian disimpan di dalam Tabut Perjanjian yang menyatakan bahwa perjanjian itu tetap dan kekal.

\section{Dipertunangkan sebagai Mempelai Kristus}

Paulus menyatakan bahwa jemaat/gereja telah dipertunangkan dengan Kristus. 2 Korintus 11:2, Sebab aku cemburu kepada kamu dengan cemburu ilahi. Karena aku telah mempertunangkan kamu kepada satu laki-laki untuk membawa kamu sebagai perawan suci kepada Kristus. Kata "mempertunangkan" dari akar kata "tunangan" dalam bahasa Yunani $\dot{\alpha} \rho \boldsymbol{\mu} \boldsymbol{o} \zeta \boldsymbol{\zeta}\left(\right.$ harmozo) artinya join or give in marriage, betroth. ${ }^{22}$

Philip E. Hughes menjelaskan hubungan Paulus dengan jemaat sebagai tunangan dari Kristus bahwa:

Paulus menggunakan sebuah metafora dari budaya perkawinan Yahudi. Ibarat seorang ayah, Paulus sudah mempertunangkan jemaat Korintus kepada Kristus (11:2). Pertunangan pada masa kuno jauh lebih serius dan mengikat daripada di zaman sekarang di kebanyakan budaya. Dalam status pertunangan, seorang lakilaki dan perempuan sudah dipandang sebagai pasangan suami-isteri. Hanya saja, mereka tidak tinggal bersama dan belum boleh melakukan hubungan seksual. Nah, seorang ayah bertanggung-jawab untuk memastikan bahwa anak gadisnya tetap perawan. Dia perlu mengingatkan anak gadisnya terus-menerus bahwa dia sudah dipertunangkan dengan "satu laki-laki" (11:2). Tidak boleh ada cinta segitiga atau perselingkuhan. Tidak boleh ada kontak seksual dengan siapapun. ${ }^{23}$

Ada suatu persoalan serius dan menjadi tantangan yang terjadi di jemaat Korintus. Para rasul palsu memberitakan "Kristus yang lain" di dalam "injil yang lain" melalui "roh yang lain" pula (11:4). Dengan segala kelicikan, mereka berusaha membanggakan diri sendiri $(5: 12 ; 10: 7,12-18 ; 11: 12)$ dan merendahkan pelayanan Paulus $(11: 5 ; 12: 11)$. Mereka menyamarkan diri mereka sebagai rasul-rasul Kristus (11:13-15). Hasilnya? Sebagian jemaat mempercayai kepalsuan yang ditawarkan. Situasi ini mendorong Paulus untuk mengirimkan surat kepada mereka. Banyak hal dia sampaikan di dalamnya. Namun, fokus pembahasan hanya pada ayat 1-6.

Sebagai tunangan Kristus, maka gereja harus memperhatikan sikap hidupnya dalam dua hal yakni (a) menjaga kesucian hidup, dan (b) menjaga kesetiaan, sebagaimana dijelaskan berikut ini.

\footnotetext{
${ }^{22}$ Bible Works 8 - version 8.0.013z.1

${ }^{23}$ Philip E. Hughes, The Second Epistle to the Corinthians, (Grand Rapids, Michigan: WM.B. Eerdmans Publishing Co, 1999), 139.
} 
Menjaga Kesucian Hidup (2Kor. 11:2)

Rasul Paulus berkata dalam 2 Korintus 11:2b, '...karena aku telah mempertunangkan kamu kepada satu laki-laki untuk membawa kamu sebagai perawan suci kepada Kristus.' Sebagaimana disampaikan oleh Dianne Bergant \& Robert J. Karris bahwa:

Orang percaya kepada Kristus (gereja) adalah tunangan, atau calon mempelai Kristus. Mereka yang sudah menerima Yesus sebagai Tuhan dan Juruselamat pribadinya, sudah mengalami lahir baru, semuanya berstatus sebagai tunangan Kristus. Tujuannya ialah untuk membawa kamu sebagai perawan suci, akan menjadi mempelai Kristus. Dalam masa pertunangan inilah jemaat Tuhan, gereja Tuhan, harus mempersiapkan diri untuk memasuki hari kemuliaan itu. Gereja, baik pria maupun wanita, tentu mengerti apa arti ungkapan 'sebagai perawan suci' dalam persiapan pernikahan itu. Mempelai pria menghendaki mempelai wanitanya sebagai perawan suci dan mempelai wanitapun menghendaki dirinya sebagai perawan suci bagi suaminya. ${ }^{24}$

Menjaga kesucian hidup sebagai perawan yang hidup dalam kekudusan. Bagaimana perasaan mempelai laki-laki jika ia mendapati mempelai wanitanya ternyata sudah tidak suci atau tidak perawan lagi? Tentunya ia akan kecewa, cemburu dan marah. Artinya mempelai wanita itu tidak bisa menjaga diri dan telah gagal mempertahankan kesucian hidupnya. Mempertahankan kesucian hidup di tengah dunia yg dipenuhi kecemaran bukanlah perkara mudah. Godaan-godaan dunia yang menawarkan kenikmatan sesaat, menyilaukan mata, dan menjanjikan materi yg melimpah membuat pertahanan iman orang percaya menjadi runtuh. Paulus memandang jemaat lokal sebagai seorang pengantin perempuan yg telah bertunangan dan akan menikah dengan Yesus Kristus (Ef.5:22;Rm.7:4). Perkawinan itu tidak akan terjadi sebelum Yesus Kristus datang untuk menjemput mempelaiNya (Wahyu 19:1-9). Sementara ini, orang Kristen secara perseorangan harus menjaga kesucian hidupnya untuk mempersiapkan diri bertemu dengan mempelai laki-laki yaitu Kristus.

Dalam masa-masa penantian jelang kedatangan Tuhan ini kita harus membentengi diri dengan perisai iman dan pedang Roh yaitu Firman Tuhan, supaya mampu bertahan di tengah godaan dunia ini. Rasul Yohanes menggambarkan sang mempelai wanita "... memakai kain lenan halus yang berkilau-kilauan dan yang putih bersih!” (Wahyu 19:8). Lenan halus melambangkan perbuatan-perbuatan kebenaran, artinya tidak sekedar cantik fisik tetapi harus hidup berkenan kepada Tuhan. Karena itu, penulis surat Ibrani 12:14 berkata “...kejarlah kekudusan, sebab tanpa kekudusan tidak seorangpun akan melihat Tuhan." Bagaimana respon sebagai mempelai wanita terhadap mempelai laki-laki dalam rangka untuk menantikan pesta pernikahan Kristus di Yerusalem baru?

\section{Menjaga Kesetiaan (2Kor.11:3)}

Apakah bahaya yang mengancam seorang yang sudah bertunangan? Bahaya yang mengancam seorang yang sudah bertunangan adalah ketidaksetiaan kepada tunangannya.

\footnotetext{
${ }^{24}$ Dianne Bergant \& Robert J. Karris, Tafsir Alkitab Perjanjian Baru, (Yogyakarta: Kanisius, 2002), 131.
} 
Perempuan yang bertunangan harus setia kepada satu orang saja tunangannya. Bila ia memberikan dirinya kepada pria lain, ia bersalah karena tidak setia. Kata "kesetiaan" dalam 2 Korintus 11:3 berarti "kesetiaan yang tulus kepada satu orang saja." yang mendua membawa kepada kehidupan yang cemar dan hubungan menjadi merusak.

Apa itu setia? Bagi orang-orang muda, setia bisa diartikan tetap menjaga hubungan sepasang kekasih. Setia itu memiliki banyak makna dan tergantung di mana kesetiaan itu akan di tempatkan. Mengasihi Tuhan adalah salah satu cara terbaik untuk menjaga kesetiaan. Di sinilah ujian kesetiaan yang sesungguhnya. Saat ingin berbuah, maka kita harus bertahan dalam menghadapi angin badai, hujan, panas, dan serangan hama. Karena itu, tetaplah percaya kepada mempelai laki-laki.

Bob Utley memberikan penjelasan tentang bagaimana jemaat sebagai tunangan dari Kristus harus menjaga hidup yang kudus, ia menyampaikan:

Gereja sebagai mempelai wanita akan bertemu dengan mempelai laki-laki di dalam pesta kawin Anak Domba. Seperti seseorang yang sudah dipertunangkan dengan orang lain, maka calon mempelai perempuan harus menjaga dan memelihara diri dalam menghadapi segala godaan yang ada. Ia harus fokus kepada pasangannya dan tidak boleh mendua dan bercabang hati. Jangan sampai pada masa-masa penantiannya ia terpikat dan berpaling kepada yang lain. ${ }^{26}$

Karena gereja telah dipertunangkan kepada Kristus, maka gereja pun harus menjadi tunangan yang setia, jangan sampai tertipu dan disesatkan oleh berbagai ajaran dan pengaruh lain di luar Tuhan yang membuat semakin jauh dari Tuhan. Inilah yang dikuatirkan rasul Paulus: "Tetapi aku takut, kalau-kalau pikiran kamu disesatkan dari kesetiaan kamu yang sejati kepada Kristus, sama seperti Hawa diperdayakan oleh ular itu dengan kelicikannya." (2Kor. 11:3).

Sebagai tunangan Kristus gereja harus tetap setia dan menjaga kekudusan sambil menantikan kedatangan-Nya sebagai mempelai laki-laki yang tidak akan lama lagi. Gereja sudah dikuduskan dan ditebus oleh darah Kristus di kayu salib, maka gereja sepenuhnya menjadi milik Kristus. Jemaat memang sudah dikuduskan di dalam Kristus. Dalam Efesus 5:26-27, Penebusan Kristus dimaksudkan "untuk menguduskannya, sesudah Ia menyucikannya dengan memandikannya dengan air dan firman, supaya dengan demikian Ia menempatkan jemaat di hadapan diri-Nya dengan cemerlang tanpa cacat atau kerut atau yang serupa itu, tetapi supaya jemaat kudus dan tidak bercela."

\section{Hari Perjamuan Kawin Anak Domba}

Puncak relasi Kristus dengan Gereja-Nya digambarkan dalam Wahyu 19:6-10 sebagai Perkawinan Anak Domba.

Lalu aku mendengar seperti suara himpunan besar orang banyak, seperti desau air bah dan seperti deru guruh yang hebat, katanya: "Haleluya! Karena Tuhan, Allah kita, Yang Mahakuasa, telah menjadi raja. Marilah kita bersukacita dan bersorak-sorai, dan memuliakan Dia! Karena hari perkawinan Anak Domba telah tiba, dan pengantin-Nya telah siap sedia. Dan kepadanya

\footnotetext{
${ }^{25}$ William Barclay, The Letters to the Corinthians, (London: Wesminster John Knox Press, 2002), 291.

${ }^{26}$ Bob Utley, Surat-surat Paulus kepada sebuah Gereja yang Bermasalah: I dan II Korintus, (Texas: Bible Lesson International, 2011), 397. Lihat file dalam bentuk PDF di: www.freebiblecommentary.org/pdf/ind/VOL06_indonesian.pdf, 14 Juli 2019.
} 
dikaruniakan supaya memakai kain lenan halus yang berkilau-kilauan dan yang putih bersih!" (Lenan halus itu adalah perbuatan-perbuatan yang benar dari orang-orang kudus) Lalu ia berkata kepadaku: "Tuliskanlah: Berbahagialah mereka yang diundang ke perjamuan kawin Anak Domba." Katanya lagi kepadaku: "Perkataan ini adalah benar, perkataan-perkataan dari Allah." Maka tersungkurlah aku di depan kakinya untuk menyembah dia, tetapi ia berkata kepadaku: "Janganlah berbuat demikian! Aku adalah hamba, sama dengan engkau dan saudara-saudaramu, yang memiliki kesaksian Yesus. Sembahlah Allah! Karena kesaksian Yesus adalah roh nubuat."

Kisah "perjamuan kawin Anak Domba" (Why. 19:6-9) adalah kisah yang kontras dengan bagian sebelumnya tentang kejatuhan si pelacur, Babel (19:1-5). Si pelacur Babel akan mati, tetapi Sang Anak Domba akan menyambut mempelai-Nya (Why. 19:69). Namun secara paradoks, keduanya - pujian kehancuran dan pujian kemenangan mengundang puji-pujian dari surga; merefleksikan kegenapan yang sempurna akan rencana Allah (Why. 19:1, 3-7).

Simon J. Kistemaker menyampaikan bahwa perjamuan kawin Anak Domba Allah merupakan puncak doksologi kepada Allah. Ia menuliskan bahwa:

Puncak doksologi kepada Allah dinarasikan dalam Wahyu 19:6-8, yaitu dalam peristiwa perjamuan kawin Anak Domba Allah. Narasi perjamuan kawin Anak Domba Allah berulangkali dipakai oleh Yesus untuk menjelaskan kedatangan Kerajaan Allah (Mat. 9:15; Mark. 2:19, 20; Luk. 3:34; Yoh. 3:29). Di Matius 25:1-13 mengisahkan tentang sepuluh gadis yang menjadi mempelai wanita menyongsong kedatangan mempelai pria. Namun hanya lima gadis yang siap menjadi mempelai wanita untuk menyambut kedatangan mempelai pria. Makna mempelai pria adalah penggambaran tentang Kristus, sedang mempelai wanita adalah penggambaran tentang gereja-Nya. Dengan demikian puncak doksologi umat kepada Allah akan terjadi pada akhir zaman, yaitu umat bersekutu dengan Kristus, Sang Mempelai Pria. Doksologi kepada Allah berpuncak pada relasi kasih yang intim antara Kristus dengan jemaat-Nya. ${ }^{27}$

Dan David J. MacLeod berkata,

"When the Bible pictures the relationship of Christ and His people as that of a husband and wife, it is expressing the truth that there is a covenant or bond between them, an everlasting union." (Ketika Alkitab menggambarkan relasi Kristus dan gereja-Nya seperti relasi antara suami dan istri, hal tersebut mengekspresikan kebenaran bahwa ada sebuah perjanjian atau ikatan di antara mereka, penyatuan selamanya). ${ }^{28}$

\section{Relasi yang Sempurna}

Setelah Yohanes mendengar seruan pujian himpunan orang banyak bagi Allah, maka dia kemudian melihat sebuah kisah pesta pernikahan Anak Domba dengan mempelai wanita-Nya. Ini merupakan puncak dari relasi yang dibangun oleh Allah yang dapat dilihat dari keseluruhan Alkitab, baik PL dan PB.

\footnotetext{
${ }^{27}$ Simon J. Kistemaker, Tafsiran Kitab Wahyu, (Surabaya: Momentum, 2009), 562.

${ }^{28}$ David J. MacLeod, 'Heaven's Hallelujah Chorus: An Introduction to the Seven 'Last Things' (Rev. 19:1-10),” Bibliotheca Sacra 156/621 (1999) 78.
} 
Di dalam PL, pernikahan menggambarkan sebuah relasi antara TUHAN dengan umat tebusan-Nya. Penggambaran tersebut mencakup tentang pertunangan (Hos. 2:2122; Yer. 2:2), pengantin wanita (Yes. 49:18; 61:10; 62:5), istri (Yeh. 16:32; Yes. 54:6), Tuhan sebagai pengantin pria (Yes. 62:5); Tuhan sebagai suami (Hos. 2:18; Yes. 54:5; Yer. 3:14; 31:32); menikah dan dinikahi (Yes. 62:4-5). ${ }^{29}$

Dalam ayat-ayat ini disebutkan tentang mempelai Pria dan wanita. Apa yang dimaksudkan? Pertama, berkenaan dengan mempelai Pria. Mempelai Pria di dalam kisah ini adalah Anak Domba. David MacLeod memberikan penafsiran bahwa: "The title 'Lamb,' more than any other, draws attention to the fact that "Christ . . loved the church and gave Himself up to her (Eph. 5:25)." Mengapa Anak Domba? Karena berkaitan dengan pengurbanan-Nya bagi umat tebusan-Nya. Sebagaimana di dalam PL (Hos. 2:14-20; Yes. 62:5; Yer. 2:2), dan PB (Mrk. 2:19; Yoh. 3:29; 2Kor. 11:2; Ef. 5:2532), Kristus digambarkan sebagai mempelai Pria. ${ }^{30}$ Jadi, dapat disimpulkan bahwa mempelai Pria yang disebut Anak Domba itu adalah Yesus Kristus yang telah menjadi kurban tebusan bagi umat-Nya.

Kedua, berkenaan dengan mempelai wanita. Sebagian besar sarjana setuju bahwa mempelai wanita yang dimaksud dalam kisah ini adalah gereja, yaitu umat Allah yang telah ditebus. ${ }^{31}$ Jika kita melihat bahasa asli yang dipakai, Wahyu 19:7 mengacu kepada kata $\dot{\eta} \gamma v v \grave{\eta}$ (he gune) yang berarti "istri", dan bukan lagi mempelai wanita $\dot{\eta}$ $v v ́ \mu \varphi \eta$ (he numphe). ${ }^{32}$ Hal ini menjelaskan bahwa Allah menyatu dengan umat-Nya dalam kemuliaan kekal selama-lamanya.

\section{Mempelai Wanita telah siap masuk dalam Kesempurnaan}

Di antara pertunangan dan pernikahan, sang mempelai wanita telah mempersiapkan dirinya. Ayat 8, "Dan kepadanya dikaruniakan supaya memakai kain lenan halus yang berkilau-kilauan dan yang putih bersih! [Lenan halus itu adalah perbuatan-perbuatan yang benar dari orang-orang kudus]”. Di dalam ayat ini, ada beberapa frasa yang harus ditafsirkan untuk memperoleh makna yang sebenarnya. Frasa tersebut yaitu: Pertama, Kain lenan halus (The finest linen). Donals A. McIlraith menjelaskan bahwa:

Sebenarnya Mempelai wanita sama sekali tidak memiliki kain lenan halus, sehingga kain lenan tersebut dikaruniakan kepadanya. Mempelai wanita hanya mengenakan kain lenan tersebut sebagai gaun pengantin, namun mempelai wanita tidak dipaksa untuk mengenakan gaun pengantinnya. Kain lenan tersebut gambaran iman, maka gaun pengantin yang terbuat dari kain lenan halus tersebut

\footnotetext{
${ }^{29}$ Namun jika kita memperhatikan lebih jauh lagi, hanya kitab Yesaya yang secara konsisten memberikan kisah tentang pernikahan untuk menggambarkan hubungan antara Tuhan dengan sisa-sisa Israel yang setia, yang disimbolkan dengan personifikasi Sion-Yerusalem. Pemaparan lebih lanjut lih. Jan Fekkes III, "The Bride has Prepared Herself: Revelation 19-21 and Isaian Nuptial Imagery," The Journal of Biblical Literature 109/2 (1990) 269.

${ }^{30} \mathrm{M}$. Eugene Boring, Interpretation: A Bible Commentary for Teaching and Preaching (Louisville: John Knox, 1989), 193.

${ }^{31}$ Sebagian besar setuju, tetapi tidak semua. Misalnya, kalangan Ultradispensasional berargumen bahwa mempelai wanita (the wife) dalam Wahyu 19 adalah Israel, dan mempelai wanita (the bride) dalam Wahyu 21 adalah gereja (E. W. Bullinger, Commentary on Revelation [Grand Rapids: Kregel, 1984] 589591).

${ }^{32}$ David E. Aune, Revelation 17-22 (3 vol.; Nashville: Thomas Nelson, 1998), 1029.
} 
diberikan sebagai penggambaran bahwa iman yang dimiliki oleh umat Tuhan adalah pemberian Allah. ${ }^{33}$

Persiapan ini menjadi bukti bahwa ada tahap-tahap yang harus dilakukan mempelai tersebut. Maka dari itu, masa persiapan bukan hanya melihat dari hasilnya, tetapi proses yang telah dikerjakan.

Kedua, Perbuatan-perbuatan yang benar dari orang kudus. Menurut Kistemaker, perbuatan yang benar mengacu kepada Efesus 2:10. Perbuatan benar hanya dimungkinkan oleh kasih karunia Allah yang bekerja di hati setiap orang percaya. Setelah bebas dari belenggu maut, orang percaya dapat melayani Tuhan sebagai bukti persembahan dirinya (Mat. 25:37-39). ${ }^{34}$ Sarjana lain mengatakan bahwa perbuatan benar yang dimaksud ada dua macam, yaitu "a righteousness of justification" dan "a righteousness of sanctification." Justification atau kebenaran adalah sesuatu yang dikaruniakan oleh Tuhan kepada manusia, sama seperti kain lenan yang dikaruniakan kepada mempelai wanita. Sedangkan sanctification atau pengudusan adalah tindakan ketaatan setiap orang percaya terhadap perintah Tuhan. Tentulah orang-orang kudus memiliki keduanya: kebenaran karena iman dan kebenaran yang menghasilkan buah pertobatan. ${ }^{35}$ Maka dari itu, dapat disimpulkan bahwa perbuatan-perbuatan benar yang dimaksud adalah perbuatan baik dari setiap orang yang telah mengalami karya penebusan di dalam Yesus Kristus, Sang Anak Domba.

\section{Konsep Pengajaran Tabernakel}

Dengan jelas Allah menyatakan tujuan pembangunan tabernakel ketika Allah memerintahkan Musa membangunnya yaitu supaya Ia berdiam di tengah umat-Nya. Dalam Keluaran 25:8, Allah berfirman kepada Musa: Dan mereka harus membuat tempat kudus bagi-Ku, supaya Aku akan diam di tengah-tengah mereka. Kemudian tujuan Allah berdiam di tengah umat-Nya dijelaskan oleh Allah melalui fungsi dari tabernakel itu, yaitu sebagai Kemah Pertemuan (Tent of Meeting) dimana Allah bertemu dengan umat-Nya (Kel. 29:4; Bil. 1:1). Artinya kehadiran Allah di tengah umat-Nya memiliki tujuan khusus yaitu Ia bertemu dengan umat dalam relasi yang harmonis.

Paulus Budiono mendeskripsikan bagaimana pembangunan Tabernakel secara fisik di padang gurun, ia menuliskan:

Kitab Keluaran pasal 25-40 adalah mengenai pembangunan dan pentahbisan Tabernakel. Mula-mula pola Tabernakel itu diberikan kepada Musa sewaktu ia berada di atas gunung Sinai 40 hari lamanya (ps 25-31). Tepat setahun setelah keluar dari Mesir (ps 40:2) akhirnya Tabernakel berdiri dan kemuliaan Allah turun memenuhinya (ps 35:40). Semuanya itu dengan maksud agar Allah akan berdiam di tengah-tengah mereka (Kel 25:8). Kitab Keluaran dengan panjang lebar menguraikan tentang Tabernakel dengan segala perabotannya. Bagian terkecil juga diuraikan dengan teliti; dan tidak kurang dari 7 kali Allah berpesan kepada Musa supaya semuanya dibuat menurut 'pola' yang telah ditunjukkan

\footnotetext{
${ }^{33}$ Donals A. McIlraith, "'For the Fine Linen is the Righteous Deeds of the Saints': Works and Wife in Revelation 19:8," The Catholic Biblical Quarterly 61/3 (1999), 525.

${ }^{34}$ Simon J. Kistemaker, Tafsiran Kitab Wahyu, (Surabaya: Momentum, 2009), 561.

${ }^{35}$ J. A. Seiss, The Apocalypse: Lectures on the Book of Revelation, (Grand Rapids: Zondervan, 1987), 428 .
} 
kepadanya 'di atas gunung' (Kel 25:9, 40; 26:30; 27:8; Bil 8:4; Kis 7:44; Ibr $8: 5){ }^{36}$

Dengan demikian, ketika TUHAN memerintahkan untuk membangun Tabernakel menjadi tempat tinggal-Nya, Musa melakukan tepat seperti yang diperintahkan TUHAN kepadanya. Inisiatif Allah untuk "diam" di tengah umat-Nya menjadi titik poin yang menjadi perhatikan dari Pengajaran Mempelai dalam Terang Tabernakel, sehingga dalam perkembangan berikutnya kehadiran Allah ini semakin jelas dinyatakan melalui Kristus dalam Yohanes 1:14, Firman itu telah menjadi manusia, dan diam di antara kita, dan kita telah melihat kemuliaan-Nya, yaitu kemuliaan yang diberikan kepada-Nya sebagai Anak Tunggal Bapa, penuh kasih karunia dan kebenaran.

\section{Kristosentris Tabernakel}

Keyakikan pada Yesus sebagai Tabernakel Sejati berangkat dari pemahaman F. G. van Gessel terhadap Yohanes 1:14, Firman itu telah menjadi manusia, dan diam di antara kita, dan kita telah melihat kemuliaan-Nya, yaitu kemuliaan yang diberikan kepada-Nya sebagai Anak Tunggal Bapa, penuh kasih karunia dan kebenaran. Ini merupakan ungkapan Roh Kudus sehingga ia membaca ayat ini menjadi "...Firman telah menjadi daging dan bertabernakel di antara kita..." Kata "diam" tersebut dibacanya "bertabernakel" (bhs. Yunani skenoo). ${ }^{37}$

Pengajaran Tabernakel yang berpusat kepada Kristus dapat terlihat pada gambar pola Tabernakel berikut ini:

Gambar 1. Yesus Kristus dalam Pola Tabernakel

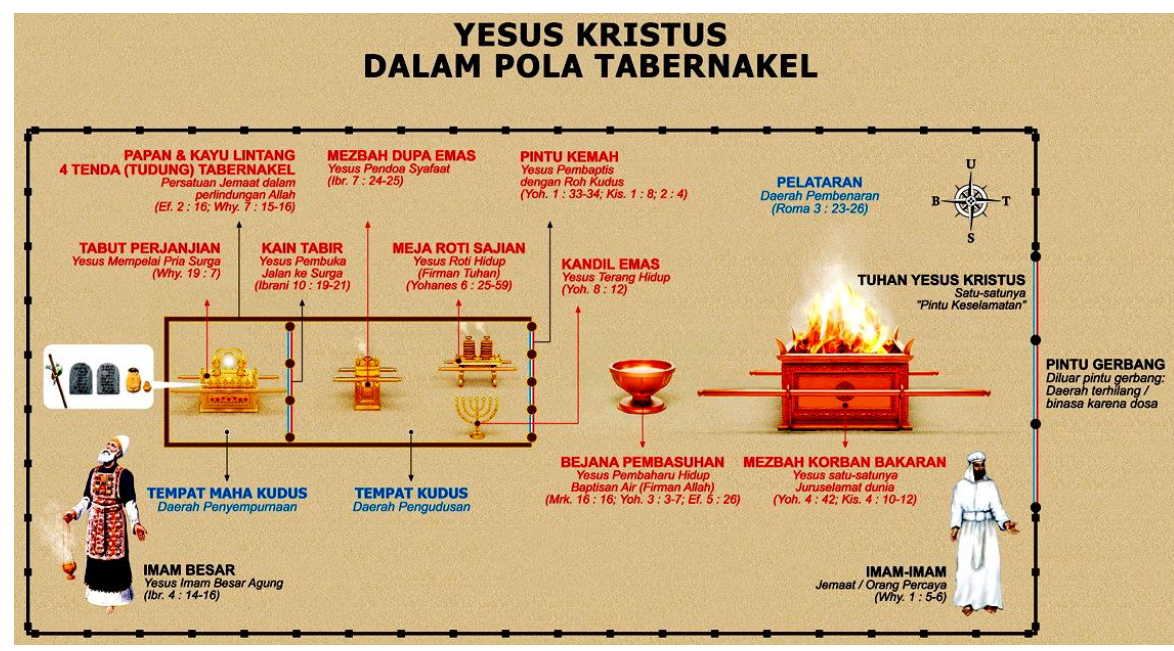

Sumber: Pdt. Paulus Budiono, 2006.

Dari gambar di atas bila diurutkan mulai dari Pintu Gerbang hingga Tabut Perjanjian, maka terlihat identifikasi terhadap Tuhan Yesus Kristus sebagai berikut: (1) Pintu Gerbang $\rightarrow$ Tuhan Yesus Kristus satu-satunya "Pintu Keselamatan", (2) Mezbah Korban Bakaran $\rightarrow$ Yesus satu-satunya Juruselamat dunia, (3) Bejana Pembasuhan $\rightarrow$

\footnotetext{
${ }^{36}$ Paulus Budiono, dkk, Pengajaran Tabernakel (Surabaya: STTIA, 2007), 12.

${ }^{37}$ Paulus Budiono, Pengajaran Tabernakel, iii.
} 
Yesus Pembaharu Hidup, (4) Pintu Kemah $\rightarrow$ Yesus Pembaptis dengan Roh Kudus, (5) Kandil Emas $\rightarrow$ Yesus Terang Hidup, (6) Meja Roti Sajian $\rightarrow$ Yesus Roti Hidup, (7) Mezbah Dupa Emas $\rightarrow$ Yesus Pendoa Syafaat, (8) Kain Tirai $\rightarrow$ Yesus Pembuka Jalan ke Surga, (9) Peti Perjanjian $\rightarrow$ Yesus Mempelai Pria Surga.

Dengan penjelasan di atas dapat ditarik suatu kesimpulan bahwa Pengajaran Tabernakel berpusat kepada Tuhan Yesus Kristus.

Pertanyaan penting terkait hal ini ialah apakah tanpa Pengajaran Tabernakel tidak dapat mengerti apa yang dimaksud Pengajaran Mempelai? Apakah tidak cukup belajar Alkitab tanpa belajar Tabernakel? Bukankah Alkitab yang mencatat dan menjelaskan mengenai Mempelai? Jawabannya ialah tanpa melihat dari perspektif Tabernakel, dapat memahami pengajaran Mempelai. Lalu mengapa penting melihatnya dari Perspektif Tabernakel? Dengan Pengajaran Tabernakel akan memberikan gambaran pemahaman yang komprehensif, terarah dan sistematis sehingga dapat memahami dengan jelas karya Kristus dalam membangun relasi dengan Gereja (umat-Nya) dan menjadikannya sebagai mempelai wanita-Nya.

Dengan demikian, Pengajaran Tabernakel memberikan gambaran yang jelas tentang karya Allah di dalam Tuhan Yesus Kristus dalam menyelamatkan manusia dan masuk dalam relasi yang sempurna. Tabernakel menjadi tools atau alat yang dapat membantu untuk memahami karya-Nya yang Agung dan sempurna. Oleh sebab itu Pengajaran Tabernakel ini begitu penting di dalam mengerti karya dan tujuan Allah bagi manusia.

\section{Tabernakel Sebagai Tools}

Dalam Pengajaran Tebernakel, dikenal dengan istilah Pola Tabernakel. Kata "pola" ini penting untuk diberi pengertian. Penggunaan kata "pola" ini berasal dari mulanya ketika Allah memberikan perintah kepada Musa untuk membangun Kemah Suci sesuai dengan contoh yang ditunjukkan kepadanya di atas gunung (Kel. 25:9, 40). Kata "contoh" di sana dalam bahasa Ibrani (tabniyth) artinya pattern (pola, contoh, desain), plan (rencana), form (bentuk), construction (konstruksi), figure (bentuk/tokoh). ${ }^{38}$ Dengan demikian, pengertian pola dalam konteks ini ialah bahwa Allah telah menetapkan contoh, pola, desain, rencana, bentuk dari Kemah Suci dan segala perabotnya untuk dibuat oleh Musa.

Kemudian penulis surat Ibrani memberikan pemahaman yang lebih luas mengenai hal ini dalam Ibrani 8:5, Pelayanan mereka adalah gambaran dan bayangan dari apa yang ada di sorga, sama seperti yang diberitahukan kepada Musa, ketika ia hendak mendirikan kemah: "Ingatlah," demikian firman-Nya, "bahwa engkau membuat semuanya itu menurut contoh yang telah ditunjukkan kepadamu di atas gunung itu." (Baca Ibr. 8:1-6). Di sini penulis Ibrani melihat bahwa pelayanan yang sejati di dalam kemah sejati ada di surga. Sedangkan pelayanan yang dilakukan oleh Harun dan anakanaknya di dalam Tabernakel di padang gurun hanyalah gambaran dan bayangan dari yang sejati. Dan pelayanan yang sejati di dalam kemah sejati dilakukan oleh Yesus Kristus secara sempurna.

Maka, "pola" yang dimaksud ialah bahwa ada suatu prinsip kebenaran yang sifatnya tetap, konsisten dan tidak berubah yang dinyatakan oleh Allah, baik dalam konteks pelayanan di kemah sejati yang ada di surga, maupun kemah sementara yang dibangun oleh Musa, dan juga pelayanan yang dilakukan oleh Kristus sebagai wujud dan

\footnotetext{
${ }^{38}$ Bible Works 8 - version 8.0.013z.1.
} 
penggenapan pelayanan sejati dalam kemah sejati yang ada di surga. Oleh karena Tabernakel Musa sebagai bayangan dan gambaran Tabernakel sejati yang ada di surga, maka pelayanan yang dikerjakan Kristus dalam kemah sejati di surga (invisible) dilihat dalam kemah suci fisik yang dibuat oleh Musa (visible). Dengan demikian, secara sederhana pengertian "Pola Tabernakel" ialah bahwa karya pelayanan Kristus dilihat dari perspektif atau sudut pandang Tabernakel secara fisik.

Namun demikian, melalui pemahaman yang komprehensif terhadap pengajaran Alkitab, maka ditemukan suatu korelasi yang signifikan dalam Alkitab bahwa Tabernakel yang dibangun oleh Musa mengandung karya besar dari Allah di dalam Yesus Kristus. Para penulis Alkitab dalam Perjanjian Baru telah memberikan identifikasi-identifikasi yang akurat bahwa tabernakel dan perabot-perabotnya menunjuk pada penggenapan yang dikerjakan oleh Kristus. Artinya apa yang dikerjakan Allah dalam Perjanjian Lama melalui Tabernakel, digenapi di dalam karya Kristus. Penjelasan ini secara sederhana dapat dilihat pada gambar berikut ini.

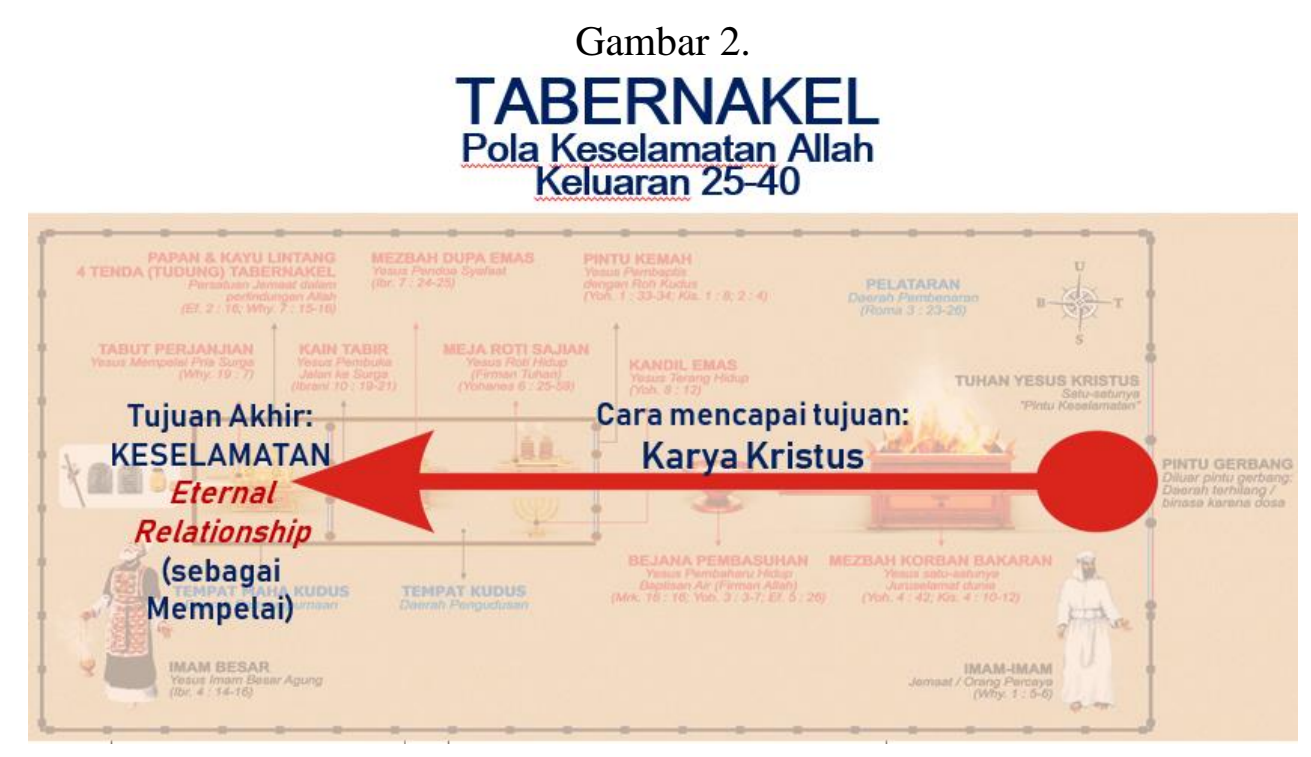

Dari gambar di atas, terlihat bahwa cara Allah untuk membagun relasi dengan umat-Nya yaitu melalui karya Kristus. Sedangkan tujuan dari karya itu ialah relasi kekal (eternal relationship) yaitu keselamatan kekal, hidup kekal bersama Allah yang digambarkan sebagai relasi Mempelai yang bersifat kekal.

Dengan demikian, apakah artinya Pola Tabernakel ini? Manakah yang lebih penting, Pola Tabernakel ini ataukah Kristus dan Karya-Nya? Jawabannya tentu Kristus dan Karya-Nya! Kalau demikian, bagaimana mendefinisikan dan mengartikan Pengajaran Tabernakel ini? Pengajaran Tabernakel merupakan pengajaran yang menyatakan Allah dan karya-Nya yang sempurna secara sistematis di dalam Kristus untuk satu tujuan yaitu terjadinya relasi Allah dengan manusia dalam relasi yang digambarkan sebagai Mempelai.

Nene Ramiantos dari Filipina salah seorang pembicara dalam BTIC di bebeberapa tempat bersama In Yuwono dan kemudian bersama Pong Dongalemba, ia mencatat dalam buku sejarah kehidupannya bahwa:

Basically, Bride Tidings International Conference (BTIC) is a holiness group of the Pentacostal variety. Its beliefs are primarily based on the teaching of the Tabernacle. Its emphasis is on the teaching of the Bride (the Church) and her preparation for the coming of her Bridegroom, Jesus and her wedding at the marriage supper of the Lamb (Pada dasarnya, Kabar Mempelai Internasional 
(KMI) adalah kelompok kesucian dari ragam Pentakosta. Keyakinannya terutama didasarkan pada pengajaran Tabernakel. Penekanannya adalah pada pengajaran Mempelai Wanita (Gereja) dan persiapannya untuk kedatangan Mempelai Pria, Yesus dan pernikahannya di perjamuan kawin Anak Domba) ${ }^{39}$

Dalam kaitannya dengan Pengajaran Tabernakel, gambaran relasi Allah (Tuhan Yesus Kristus sebagai Mempelai Pria Surga) dengan gereja sebagai mempelai wanita dilukiskan dalam Peti Perjanjian (The Ark of the Covenant) pada gambar 3 berikut.

\section{Gambar 3. Tabut Perjanjian (The Ark of the Covenant)}

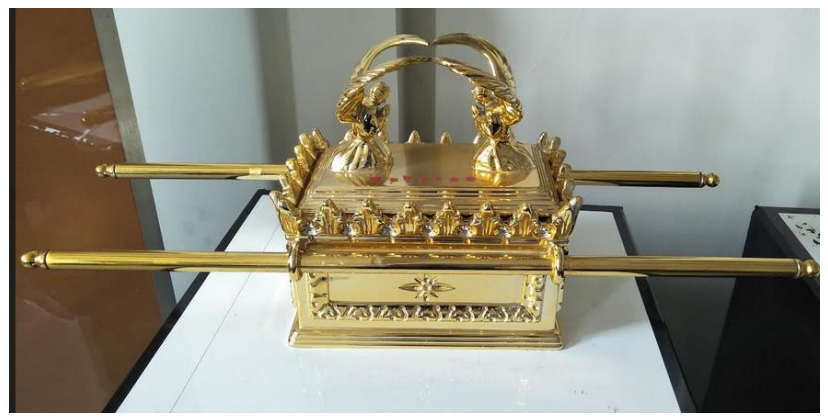

Sumber: Foto Miniatur Tabernakel di STT Tabernakel Indonesia Surabaya, 2019

Tabut Perjanjian terdiri dari 2 bagian yaitu tutup pendamaian dan tabut/peti (Kel. 25:10-22), sedangkan isinya ialah dua loh hukum (Kel. 25:16); buli-buli berisi manna (Kel. 16:22); dan tongkat Harun yang bertunas (Bil. 17:8-10, bnd. Ibr. 9:4).

Pertama, Tutup Pendamaian dengan dua kerub di atasnya yang melambangkan Tuhan Yesus Kristus sebagai Mempelai Pria Surga. Paulus Budiono menjelaskan hal ini dalam tulisannya bahwa:

Pelajaran rohani yang dapat diambil dari Tutup Pendamaian adalah:

a) Tutup Pendamaian gambaran penebusan. Tabut dan Tutup disatukan menyatakan penyatuan kemanusiaan dan keilahian dalam wujud Yesus Kristus sebagai Anak Allah dan Anak Manusia; juga menunjuk pada penyatuan antara Kristus (Tutup Pendamai) dengan Mempelai PerempuanNya (Tabut Perjanjian) saat 'pernikahan Anak Domba' tiba.

b) Alkitab mengatakan bahwa Yesus adalah Pendamai atau Penebus kita (Rom. 3: 24-25). Kata "Pendamai" ini dalam bahasa Yunani adalah "Hilasteron" yang mempunyai arti "Tempat Pendamaian" dan kata ini juga dipakai dalam Alkitab bahasa Yunani untuk "Tutup Pendamaian", maka Yesus itulah Tutup Pendamaian kita.

c) Kemuliaan Allah datang untuk tinggal di tengah-tengah Kerub-kerub pada Takhta Pendamaian. Menggambarkan hadirat Tuhan berada ditengah tengah GerejaNya (Ibr. 9:5). ${ }^{40}$

Berdasarkan penejelasan di atas menunjukkan gambaran Kristus sebagai Pendamai dan Penebus melalui Tutup Pendamaian (Mersy Seat) dalam relasi dengan gereja-Nya yakni tubuh-Nya.

\footnotetext{
${ }^{39}$ Nene Ramiantos, From Sand to the Stars and Beyond (America: Heart of Worship Community Media Ministry, 2009), 93.

${ }^{40}$ Paulus Budiono, dkk., Pengajaran Tabernakel, 91.
} 
Kedua, Peti yang melambangkan Gereja Tuhan sebagai Mempelai Wanita-Nya. Lebih lanjut Paulus Budiono menjelaskan tentang Gereja sebagai Mempelai Wanita dalam relasinya dengan Kristus sebagai Mempelai Pria Surga, ia menulis bahwa:

Tabut menggambarkan Gereja Tuhan (Tubuh-Nya), yang juga disebut Mempelai Perempuan Anak Domba (bnd. Ef 5:30), maka 'wadah' ini harus terisi 3 hal yang bersifat permanen:

a) Manna dalam buli-buli emas, menunjuk pada Roti dari Sorga gambaran Yesus adalah Roti Hidup (Firman Allah yang kekal (baca: Maz. 119:89, 11; bnd. Yoh. 6:68, 69; Mat. 24:35; 1Ptr. 1:23-25).

b) Tongkat Harun yang pernah bertunas, berbunga dan berbuah, yang menunjuk pada karya Roh Kudus yang kekal sebagai bukti adanya hidup Kristus dalam diri orang percaya (baca: Gal. 5:22,23; Ef 5:9 "fruit of the Spirit"; bnd. Yoh. 14:16 "Comforter ... abide wih your for ever"; 1 Yoh 3:24; Ibr 9:14; Kej. 1:2 dan Why. 22:17).

c) Dua loh batu, yang menunjuk pada Firman Allah adalah sumber hukum kasih (anugerah) dari Kasih (Allah Bapa) yang tak berkesudahan (baca: Mat 22:3640; bnd. 1 Kor 13 ; 2 Kor $3: 3) .{ }^{41}$

Berdasar penjelasan di atas dapat dipahami bahwa Tutup Pendamaian dan Tabut dijelaskan secara terpisah dalam relasi Kristus dengan Gereja-Nya dalam persekutuan atau relasi yang kekal sebagai Mempelai.

\section{PENUTUP}

Pengajaran Mempelai dalam Terang Tabernakel telah memberkati banyak orang sehingga mengalami pertumbuhan iman dan pengenalan kepada Allah. Pengajaran yang begitu kuat dalam membangun relasi dengan Allah dan juga dengan sesama. Tidak dapat dipungkiri bahwa pengajaran ini telah memberikan warna dalam kehidupan bergereja di Indonesia khususnya di kalangan jemaat di Gereja Pantekosta Tabernakel (GPT).

Pengajaran Mempelai dalam Terang Tabernakel merupakan karya yang luar biasa dari F. G. van Gessel yang dilanjutkan oleh murid-muridnya terutama In Yuwono, sebagai upaya dalam memberikan pemahaman Alkitab secara komprehensif dari perspektif pola Tabernakel. Pengajaran Mempelai dalam Terang Tabernakel yang berdasarkan Alkitab memiliki nilai guna yang sangat baik bagi pertumbuhan iman jemaat dalam relasinya dengan Allah dan sesama. Pengajaran yang memberikan arah dan tujuan hidup manusia yang digambarkan dalam pola Tabernakel bersifat menolong dan menuntun setiap orang yang percaya kepada Kristus sebagai Mempelai Pria Surga. Pengajaran ini harus dilihat sebagai sarana yang menunjukkan jalan kebenaran.

Pengajaran Mempelai dalam Terang Tabernakel suatu dimensi penting dalam memahami kebenaran Firman Tuhan dalam membawa Gereja Tuhan mengalami pertumbuhan dan kedewasaan iman hingga mencapai relasi yang intim dengan Allah di dalam Yesus Kristus sebagai Mempelai, dan juga membawa pada kesatuan dengan sesama anggota tubuh Kristus yang dimulai dari keluarga (nikah).

Oleh sebab itu perlu didalami dan dipertanggungjawabkan sebagai kebenaran tanpa menyisisihkan dimensi-dimensi lain dalam memahami Alkitab. Pengembangan Pengajaran Mempelai dalam Terang Tabernakel hendaknya dibangun atas dasar kebenaran Firman Tuhan melalui pembelajaran Alkitab yang lebih mendalam. Perlu

\footnotetext{
${ }^{41}$ Paulus Budiono, dkk., Pengajaran Tabernakel, 87-88.
} 
suatu keterbukaan terhadap pandangan dan perspektif yang lain dalam memahami Alkitab untuk mempertajam pemahaman terhadap kebenaran Alkitab.

Gereja sebagai representatif Kristus di dunia ini memiliki tugas dan tanggung jawab menghadirkan kasih Kristus melalui sikap hidup di tengah-tengah dunia. Menjadi saksi Kristus melalui Pengajaran Mempelai dalam Terang Tabernakel tidak hanya dalam tataran konsep dan teori tetapi harus dibuktikan dengan sikap dan perbuatan sebagai calon-calon Mempelai Kristus yang telah mengalami keubahan hidup. Sikap eksklusif yang membatasi ruang gerak sehingga tidak mampu melihat kekayanan yang ada dalam memahami kebenaran Alkitab perlu dikaji ulang. Alkitab harus menjadi standar penilaian kebenaran.

\section{Daftar Pustaka}

Aune, David E. Revelation 17-22 (3 vol; Nashville: Thomas Nelson, 1998.

Barclay, William. The Letters to the Corinthians. London: Wesminster John Knox Press, 2002.

Bergant, Dianne \& Karris, Robert J. Tafsir Alkitab Perjanjian Baru. Yogyakarta: Kanisius, 2002.

Boring, M. Eugene. Interpretation: A Bible Commentary for Teaching and Preaching. Louisville: John Knox, 1989.

Budiono, Paulus, dkk. Pengajaran Mempelai. Surabaya: SAPTA KMI, tt. , Pengajaran Tabernakel. Surabaya: STTIA, 2007.

Julianti, Lidya \& Tim, Biografi F. G. van Gessel. Surabaya: SAPTA KMI, tt.

Kistemaker, Simon J. Tafsiran Kitab Wahyu. Surabaya: Momentum, 2009.

Gereja Panteksota Tabernakel, (https://id.wikipedia.org/wiki/Gereja_Pantekosta

Tabernakel, 17 Juli 2019)

Sejarah Gereja, (http://gptkk.org/m/sejarah.php, 19 Juli 2019)

Wijanarko, Jarot. Mempelai Ilahi, (Jakarta: KIB, 2017), 16.

Kuiper, A. de. Tafsiran Alkitab - Kitab Hosea, (Jakarta: BPK Gunung Mulia, 2003), 55.

Strong's Concordance, https://biblehub.com/hebrew/3045.htm, 07 Juli 2019.

Hughes, Philip E. The Second Epistle to the Corinthians. Grand Rapids, Michigan:

WM.B. Eerdmans Publishing Co, 1999.

MacLeod, David J. "Heaven's Hallelujah Chorus: An Introduction to the Seven 'Last Things' (Rev. 19:1-10)," Bibliotheca Sacra 156/621 (1999).

McIlraith, Donals A. 'For the Fine Linen is the Righteous Deeds of the Saints': Works and Wife in Revelation 19:8," The Catholic Biblical Quarterly 61/3 (1999).

Pengajaran Kabar Mempelai (http://kabar-mempelai.blogspot.com/, 19 Juli 2019)

Ramiantos, Nene. From Sand to the Stars and Beyond. America: Heart of Worship Community Media Ministry, 2009.

Sejarah GPT, (https://id.wikipedia.org/wiki/Gereja_Pantekosta_Tabernakel, 13 Juli 2010).

Sejarah Gereja (http://gptkk.org/m/sejarah.php, 19 Juli 2019)

Seiss, J. A. The Apocalypse: Lectures on the Book of Revelation. Grand Rapids: Zondervan, 1987.

Utley, Bob. Surat-surat Paulus kepada sebuah Gereja yang Bermasalah: I dan II

Korintus. Texas: Bible Lesson International, 2011. File dalam bentuk PDF di: www.freebiblecommentary.org/pdf/ind/VOL06_indonesian.pdf, 14 Juli 2019. 